\title{
Analysis of Stunting Incidence Factors in Toddlers Aged 23-59 Months in the Work Area of the Padang Tiji Community Health Center, Pidie Regency, 2020
}

\author{
Fauziah Andika ${ }^{1}$, Marniati ${ }^{2}$, Nuzulul Rahmi ${ }^{2}$, Chairanisa Anwar ${ }^{3}$ \\ Asmaul Husna ${ }^{4}$, Faradilla Safitri ${ }^{5}$ \\ 1,2,3,4,5Fakultas Ilmu Kesehatan, Universitas Ubudiyah Indonesia \\ ${ }^{*}$ Corresponding Author: \\ Email : nuzulul_r@uui.ac.id
}

\begin{abstract}
.
Aceh is ranked third nationally for child stunting, behind East Nusa Tenggara (NTT) and West Sulawesi (Sulbar). Currently, he explained, the government is aggressively campaigning for the prevention and handling of stunting. This is because the prevalence of stunting for infants under five years of age (toddlers) in Indonesia in 2018 was $30.8 \%$. Based on a report from Puskesmas Padang Tiji in 2018, there were $114(18.4 \%)$ toddlers aged 23-59 months who experienced stunting, while in 2019 it increased to 138 (20.9\%) toddlers with stunting. The purpose of this study was to analyze the incidence of stunting in children aged 23-59 months in the Padangtiji Community Health Center in 2020. This research method uses a case control approach. In the study, the control samples were toddlers who came to Posyandu who were randomly selected. The research sample was 50 cases and 50 controls, namely 1: 1. This research was conducted on December 10, 2020 to December 21, 2020. The statistical test used is the chi-square test by looking at the $O R$ value and data analysis using univariate and bivariate analysis. The results of this study were the relationship between the incidence of stunting with exclusive breastfeeding $(P=0.016)(O R=3.071)$, birth weight $(P=0.678)$, infectious diseases $(P=0.523)$ and birth spacing $(P=0.043)(O R=2,421)$. The conclusion of this study is that there is a relationship between exclusive breastfeeding and birth spacing with the incidence of stunting in toddlers aged 23-59 months in the working area of Puskesmas Padang Tiji in 2020. The suggestions are expected to further improve health promotion in the form of counseling related to the causes and prevention of stunting in order to increase knowledge mothers regarding stunting and prevention related to infectious diseases in reducing morbidity that can lead to stunting.
\end{abstract}

Keywords: Incidence of stunting, exclusive breastfeeding, low birth weight, birth distance and infectious diseases

\section{INTRODUCTION}

Stunting is a linear growth disorder caused by malnutrition of chronic nutrient intake and or chronic or recurrent infectious diseases indicated by a $\mathrm{Z}$ score of height by age (TB/U) less than -2 standard deviation (SD) (Kemenkes, 2016). Nutrition Status Monitoring (PSG) 2017 shows the prevalence of stunting toddlers in Indonesia is still high, which is $29.6 \%$ above the limit set by WHO, namely $20 \%$ (Ministry of Health, 2018). Growth and developmental disorders that occur in infancy is a condition that can not be underestimated considering the impact that will be faced by children 
with stunting in adulthood. Some factors that are suspected to affect stunting events include the history of illness, maternal employment status, maternal education status, gender, number of family members, primary caregivers, nutritional fulfillment patterns, parenting patterns, toddler birth weight, toddler health care patterns, per capita income, maternal knowledge about nutrition and birth length (Anugraheni, 2012).

Malnutrition and stunting are two interconnected problems. Stunting in children is the impact of nutrient deficiency during the first thousand days of life. This leads to irreversible physical developmental impairment of the child, resulting in decreased cognitive and motor abilities as well as decreased work performance. Stunting children have an average Intelligence Quotient (IQ) score eleven points lower than the average IQ score in normal children. Developmental disorders in children due to malnutrition if they do not get intervention early will continue into adulthood (Ministry of Health, 2016).

Stunting in toddlers needs to get special attention because it can lead to stunted physical growth, mental development and health status in children. Recent studies show stunting children are associated with poor school performance, low levels of education and low incomes in adulthood. Stunted children are more likely to grow into unhealthy and poor adult individuals. Stunting in children is also associated with increased susceptibility of children to diseases, both infectious and non-communicable diseases (PTM) as well as an increased risk of overweight and obesity. Long-term overweight and obesity conditions can increase the risk of degenerative diseases. Cases of stunting in children can be used as predictors of the low quality of human resources of a country. Stunting causes poor cognitive ability, low productivity, and increased risk of disease resulting in long-term losses to the Indonesian economy (Trihotno. Et.al, 2015).

Stunting is a problem caused by multifactors. Individual factors as well as family factors can cause stunting. The adverse effects that will arise from stunting events in the short term are impaired intellectual intelligence, brain development, physical and metabolic disorders in children. Children who experience stunting before the age of 6 months, will experience impaired growth so that there is a heavier stunting towards the age of two years. While the long-term impact of stunting is the large risk of developing non-communicable diseases, deteriorating health, intellectual or intelligence and educational achievement in childhood - children become bad (Tsaralatifah, 2020).

Aceh is ranked third nationally for stunting toddlers, below East Nusa Tenggara (NTT) and West Sulawesi (sulbar). Currently, he explained, the government is actively campaigning for the prevention and handling of stunting. Because, the prevalence of stunting infants under five years old (toddlers) Indonesia in 2018 is $30.8 \%$. This figure is above the WHO-set threshold of $20 \%$. In addition, in Southeast Asia, Indonesia is also ranked second only to Laos. The cause of stunting is many things or multifactors. Therefore, the solution must also be done in a multisector. This is where the commitment of state leaders must be strong, which is further continued at the level of 
regional leaders to districts and cities. In particular, appreciation should be given to the Government of Aceh because in the last five years the Government of Aceh was able to reduce the prevalence of stunting from $41.5 \%$ in 2013 to $37.3 \%$ in 2018 , which means the Government of Aceh saved 18 thousand toddlers from stunting. Nevertheless, Aceh still has to work hard because it is currently ranked as the third highest stunting prevalence in Indonesia (Aripin et al., 2018).

Based on a report from Puskesmas Padang Tiji in 2018, toddlers aged 23-59 months who experienced stunting as much as 114 (18.4\%) toddlers while in 2019 increased to $138(20.9 \%)$ toddler with stunting. Many factors that cause toddlers to experience stunting, including food intake, infectious diseases and income. Based on the data above researchers are interested to know what factors affect stunting in toddlers aged 23-59 months in the working area of Padang Tiji Health Center in 2020.

\section{METHODS}

This research method uses a case control approach. In the study that became a control sample was a toddler who came to Posyandu who was selected randomly. The sample of this study is 50 cases and 50 controls, which is $1: 1$. This research was conducted from December 10, 2020 to December 21, 2020. Statistic test used is chisquare test by looking at OR value and data analysis using univariate and bivariate analysis.

\section{RESULT AND DISCUSSION}

Table 1. Distribution of Frequency of Stunting Events, Exclusive Breast Milk, Birth weight, infectious diseases and birth distance in Padangtiji Health Center in 2020

\begin{tabular}{c|lcc}
\hline NO & \multicolumn{1}{|c}{ VARIABLE } & FREQUENCY & PERCENTAGE (\%) \\
\hline $\mathbf{1}$ & Stunting Events Stunting & 50 & 50 \\
& -Stunting & 50 & 50 \\
$\mathbf{2}$ & -No Stunting & & \\
& Birth Weight & 6 & 6 \\
& -Abnormal (<2500gr) & 94 & 94 \\
$\mathbf{3}$ & -Normal (>2500 gr) & & 49 \\
& Exclusive Breast Milk & 49 & 51 \\
& -Not Eksklusive & 51 & \\
& - Exclusive Breast Milk & & \\
& & & 11 \\
$\mathbf{4}$ & Infection Disease & 11 & 89 \\
& -There & 89 & 43 \\
$\mathbf{5}$ & -There's No & & 57 \\
& Birth Distance & 43 & 57 \\
& -Risk & 57 & $(2500$ \\
\hline
\end{tabular}

Based on table 1. it can be seen that toddlers with normal birth weight ( $>2500$ grams) are $94 \%$ greater than toddlers born $<2500$ grams of $6 \%$. Toddlers with exclusive breast milk were $51 \%$ larger than infants who were not given exclusive $49 \%$. While the http://ijstm.inarah.co.id 
variable infectious diseases, many toddlers who have never experienced an infectious disease is $89 \%$ greater than those who have experienced infectious diseases that is $11 \%$. Furthermore, at birth distance, the greater the risk than the not at risk, which is $57 \%$.

Tabel 2. Hubungan Antara ASI Eksklusif, Berat Badan Lahir, Penyakit Infeksi dan Jarak Kelahiran dengan Kejadian Stunting pada Balita Usia 23-59 Bulan di Wilayah Puskesmas Padang Tiji Tahun 2020

\begin{tabular}{|c|c|c|c|c|c|c|c|}
\hline \multirow[t]{3}{*}{ No } & \multirow[t]{3}{*}{ Variable } & \multicolumn{4}{|c|}{ Stunting Events } & \multirow[t]{3}{*}{ p value } & \multirow[t]{3}{*}{ OR } \\
\hline & & \multicolumn{2}{|c|}{ Stunting } & \multicolumn{2}{|c|}{ No Stunting } & & \\
\hline & & $\mathbf{n}$ & $\%$ & $\mathbf{n}$ & $\%$ & & \\
\hline \multirow[t]{3}{*}{1} & Exclusive Breast Milk & & & & & & 3.071 \\
\hline & a.Not Eksklusive & 31 & 62 & 18 & 36 & & $(1.353-$ \\
\hline & b.Exclusive Breast Milk & 19 & 38 & 32 & 64 & 0.016 & $6.972)$ \\
\hline \multirow[t]{3}{*}{2} & Birth Weight & & & & & & \\
\hline & a.Abnormal (<2500gr) & 4 & 8 & 2 & 4 & & \\
\hline & b.Normal (>2500 gr) & 46 & 92 & 48 & 96 & 0.678 & - \\
\hline \multirow[t]{3}{*}{3} & Infection Disease & & & & & & - \\
\hline & a.There & 4 & 8 & 7 & 14 & 0.523 & \\
\hline & b.There's No & 46 & 92 & 43 & 86 & & \\
\hline \multirow[t]{3}{*}{4} & Birth Distance & & & & & & 2. 421 \\
\hline & a. $<24$ months & 27 & 54 & 16 & 32 & & $(1.071-$ \\
\hline & b. $>24$ months & 23 & 46 & 34 & 68 & 0.043 & $5.475)$ \\
\hline
\end{tabular}

\section{A. Relationship of Birth Distance with Stunting Incidence in Toddlers aged 23-59 months}

Based on Table 5.5 shows that the birth distance of $<24$ months leih risked to experience stunting incidence by $54 \%$ greater compared to toddlers who do not stunting is $32 \%$. Statistic test results obtained the value of $\mathrm{P}=0.043$, meaning there is a significant relationship between the distance of birth and stunting events in toddlers in PadangTiji Health Center year 2020. Based on the or value obtained results of 2,421, meaning that toddlers who experience stunting have a 2 times greater chance if the previous birth distance $<24$ months. This study is not in accordance with the study from Nadiyah (2014) the birth distance has a value of P-Value $0.0628(>0.05)$ so it can be concluded that there is no significant relationship between the distance of birth and stunting in children. This is influenced by the small number of samples while the number of variables studied is large. The results of this study are in line with research conducted by Nadiyah (2014), birth distance is not significant related to stunting with nila $\mathrm{p}$-value $0.176(\mathrm{p}<0.05)$.

Sufficient birth distance allows the mother to recover perfectly from the condition after childbirth. When the mother is comfortable with her condition, the mother can create a good parenting pattern in parenting and raising her child (Santrock, 2002). The safe birth distance is between 2-4 years. The distance between 2 pregnancies that need to be watched because of the possibility of poor fetal growth, prolonged childbirth or bleeding. Conversely, if the pregnancy distance between two pregnancies $\geq 2$ years, in addition to the increasing age of the mother also results in childbirth such as pregnancy and first childbirth (Ministry of Health RI, 2007). 
Based on the assumption from researchers that birth distance affects stunting events. If the birth distance is $<24$ months then the risk of toddlers will experience stunting and there are also other factors other than the birth distance of child 1 with the 2nd child or the next child. Other factors that can affect stunting events are maternal knowledge factors and also exclusive breastfeeding in infants for 6 months without providing additional food.

\section{B. Exclusive Breastfeeding Relationship with Stunting Incidence in Toddlers aged 23-59 months}

Based on the table of exclusive breastfeeding relationship with stunting incidence showed that toddlers who were not given Exclusive breast milk by $62 \%$ experienced stunting, greater than toddlers who did not stunting by $36 \%$. Statistical test results obtained a value of $\mathrm{P}=0.016$, meaning there is a relationship between Exclusive breast milk and stunting events. The value of EXCLUSIVE breast milk with stunting event is 3,071, meaning toddlers who are not given Exclusive breast milk have a 3 times greater chance of stunting.

This research is in line with research Exclusive breastfeeding relationship with stunting incidence in toddlers 2-3 years. Where obtainedmagnitude-value $=0.000$ $(0.000<0.05)$. So it was concluded that there is an exclusive breastfeeding relationship with stunting events in toddlers 2-3 years. Breast milk is a nutritional intake that is in accordance with the needs will help the growth and development of children. Babies who do not get enough breast milk means they have poor nutritional intake and can cause malnutrition, one of which can lead to stunting. (Indrawati, 2016).

In accordance with Prasetyono (2009) that one of the exclusive benefits of breast milk is to support the growth of infants, especially height because calcium breast milk is more efficiently absorbed than breast milk substitute milk or formula milk. So babies given exclusive breast milk tend to have a higher height and in accordance with the growth curve compared to babies given formula milk. Breast milk contains more calcium and can be absorbed by the body well so as to maximize growth, especially height and can avoid the risk of stunting

Researchers argue, that toddlers who are given exclusive breast milk are not at risk of stunting events, because enough is given breast milk at the time of infancy. Breast milk can also improve the nutritional status of babies so that many babies in the working area of Padangtiji Health Center are not stunted. Although Exclusive breast milk is one of the factors that influence stunting events, there are other factors that affect stunting events, one of which is income from the family. The higher the income, the better the nutritional status in toddlers.

\section{Relationship of Infectious Diseases with Stunting Incidence in Toddlers aged 23-59 months}

Based on the table of infectious diseases with stunting incidence in toddlers aged 23-59 months showed that toddlers who had experienced infectious diseases and did not experience stunting incidence was $14 \%$ greater than toddlers who experienced stunting by $8 \%$. Statistic test results obtained a value of $\mathrm{P}=0.523$, meaning there is no connection with infectious diseases with stunting events in toddlers in Padang Tiji Health Center in 2020. 
This study is not in accordance with dewi research (2018) chi-square statistical test results in clown stunting and non stunting is known that $p=0.049$ which means that there is a link of infectious disease status in clown stunting and non stunting. In addition, an OR (Odds Ratio) value of 3,071 (95\% CI: 1,155 - 11,861) was obtained. The OR score means that clown children who have an infectious disease in the last 3 months are 3,071 times more at risk of stunting compared to clowns who do not have an infectious disease.

In the history of infectious diseases stunting toddlers both in the village and in the city mostly have a history of infectious diseases with a percentage of $100 \%$ in both areas. Based on the results of the chisquare test, it is known that the history of infectious diseases with stunting events in toddlers in rural and urban areas has a significant relationship with successive pvalue values of 0.017 and $0.001<\alpha(0.05)$. In the status of low birth weight (BBLR) in stunting toddlers both in the village and in the city most are not BBLR with a percentage of $74.2 \%$ in the countryside, while for the city is $93.3 \%$, while in the genetic factors stunting toddlers who are in the village and city areas are mostly affected by genetic factors with a percentage of $80.6 \%$ for the countryside, while in urban areas that is $53.3 \%$. Based on the results of bivariate tests on both variables showed that BBLR with stunting incidence in toddlers in rural and urban areas did not have a significant relationship, while for genetic factors it can be known that there is a significant relationship with stunting events in toddlers both in rural and urban areas.

Based on the assumption from researchers that toddlers who have experienced infectious diseases are not necessarily toddlers experiencing stunting events. Because there are other factors that affect toddlers experiencing stunting events, namely the distance of birth and exclusive breastfeeding.

\section{Relationship of Birth Weight with Stunting Incidence in Toddlers aged 23-59 months}

Based on Table 5.3 shows that toddlers with abnormal birth weight $(<2500$ grams) experienced stunting $8 \%$ greater compared to those who did not stunting by $4 \%$. Statistic test results obtained $\mathrm{P}$ Value $=0.678$, meaning there is no relationship between birth weight and stunting events in toddlers in PadangTiji Health Center year 2020.

The results of this study are not in line with Dewi's research (2018) showing that stunting and non stunting clowns mostly have a normal birth weight. The results of the chisquare statistical test showed that there is a relationship of clown birth weight with stunting with a $p$-value of $p=0.042$ which means that there is a relationship of low birth weight in stunting and non stunting clowns. Then obtained or value (Odds Ratio) of 0.157 (95\% CI: $0.030-0.822)$, OR value means that clown children who have a history of BBLR 0.157 times greater risk of stunting compared to clowns who do not experience BBLR. uta that do not experience BBLR. Bblr results with low odds ratio results due to the number of clown stunting and non stunting mostly have a normal weight although the number of stunting clowns is more bblr (35\%) than non stunting clowns (8\%). This can be due to the economic status of the family, from the results of the study found parents of stunting clowns have a lower income level of MSEs than non stunting which is $92.3 \%$. 
Poor hygiene practices can lead to the appearance of bacteria. Bacteria can enter through food that is usually served can affect the health of the child, one of which arises diarrheal diseases and can cause the child to lose fluids and a number of nutrients that are essential for the body (Welasih, 2012). A child affected by diarrhea will experience malnutrition malabsorbsi and the duration of diarrhea that lasts a long time (more than four days) will make the child increasingly lose nutrients, if not immediately handled with the appropriate intake then it can happen to fail to grow . Diarrhea that occurs in the first two years of life can affect the occurrence of growth retardation (Batiro, 2017). Malnourished children will have low resistance to infectious diseases such as diarrhea and ISPA that affect children's cognitive development and inhibit growth (Wellina, 2016).

The assumption from researchers that birth weight has no effect on stunting events in toddlers. Because the baby's weight is low if the baby is given adequate nutrition and given exclusive breast milk for 6 months without being given additional food, it can improve nutrition in the baby. So that toddlers will not experience stunting events.

\section{CONCLUSION}

Based on the research that has been done, it can be concluded that there is a relationship between exclusive breastfeeding and birth distance with stunting events with a value of $\mathrm{P}<0.05$ with a value of $\mathrm{OR}=3.071$ and $\mathrm{OR}=2.421$, respectively. While birth weight and infectious diseases with stunting incidence have no relationship with the value of $\mathrm{P}<0.05$

\section{REFERENCES}

[1] Aripin, A., Dwiriani, S. M., Meti, C., \& Kolopaking, R. 2018. Asupan Gizi Mikro: Defisiensi Besi Dan Stunting Pada Anak Usia 6-23 Bulan Di Aceh, Indonesia. Widyakarya Nasional Pangan Dan Gizi (WNPG) “ Percepatan Penurunan Stunting Melalui Revitalisasi Ketahanan Pangan Dan Gizi Dalam Rangka Mencapai Tujuan Pembangunan Berkelanjutan.”

[2] Aridiyah, Okky Farah. Ninna Rohmawati, Mury Ririanty. 2015. Faktor-faktor yang Mempengaruhi Kejadian Stunting pada Anak Balita di Wilayah Pedesaan dan Perkotaan. e-Jurnal Pustaka Kesehatan, vol. 3 (no. 1) Januari 2015.

[3] Anugraheni, et al. 2012. Faktor Risiko Kejadian Stunting Pada Anak Usia 12-36 Bulan di Kecamatan Pati, Kabupaten Pati. Undergraduate thesis, Diponegoro University .http://eprints.undip.ac.id/3839 3/

[4] Badan Penelitian dan Pengembangan Kesehatan Kementerian Kesehatan RI. 2013. Riset kesehatan dasar (Riskesdas). Jakarta: Balitbang Kemenkes RI; 2013.

[5] Batiro, B., Demissie, T., Halala, Y. \& Anjulo, A. A.2017. Determinants of stunting among children aged 6-59 months at Kindo Didaye woreda, Wolaita Zone, Southern Ethiopia: Unmatched case control study. PLoS One 12, 1-15.

[6] Candra A. 2013. Hubungan Underlying Faktors Dengan Kejadian Stunting pada Anak 1-2 th. Journal of Nutrition and Healt, Vol. 1, No.1. dari http://www.ejournal. undip.ac.id 
[7] Kementerian Kesehatan RI. 2016. Peraturan menteri kesehatan republik indonesia nomor 39 tahun 2016 tentang pedoman penyelenggaran program Indonesia sehat. Jakarta: Kemenkes RI; 2016

[8] Kemenkes. 2018. Ini Penyebab Stunting Pada Anak. http://www. depkes.go.id/ article/ view/18052800006/ini-penyebab -stunting-pada-anak.html

[9] Kementerian Perencanaan Pembangunan Nasional/ Badan Perencanaan Pembangunan Nasional.2007. Rencana aksi nasional pangan dan gizi 2006-2010. Jakarta; 2007.

[10] Nadiyah. 2014. Faktor Risiko Srtunting Pada Anak Usia 0-23 Bulan Di Provinsi Bali, Jawa Barat, Dan Nusatenggara Timur. Jurnal gizi dan pangan, Juli 2014, 9(2): 125-132

[11] Dewi, Novianti Tysmala. Dhenok Widari. 2018. Hubungan Berat Badan Lahir Rendah dan Penyakit Infeksi dengan Kejadian Stunting pada Baduta di Desa Maron Kidul Kecamatan Maron Kabupaten Probolinggo. Jurnal: Amerta Nutr (2018) 373-381. Open acces tanggal 04 Januari 2021.

[12] Tsaralatifah. Amerta Nutr .2020.Faktor yang Berhubungan dengan Kejadian Stunting pada Baduta di Kelurahan Ampel Kota Surabaya. Joinly Published by IAGIKMI \& Universitas Airlangga. Akses tanggal 5 Januari 2020

[13] Trihono, Atmarita, Tjandrarini DH, Irawati A, Utami NH, Tejayanti T, et al.2015. Pendek (stunting) di Indonesia, masalah dan solusinya. Jakarta: Lembaga Penerbit Balitbangkes; 2015.

[14] Indrawati.Sri , Warsiti.2016. Hubungan Pemberian ASI Eksklusif Dengan Kejadian Stunting Pada Anak Usia 2-3 Tahun Di Desa Karangrejek Wonosari Gunung kidul. UNIVERSITAS 'AISYIYAH YOGYAKARTA http://digilib.unisayogya.ac.id/2480/1/dira\%20Naskah\%20Publikasi\%20.pdf diakses tanggal 4 Januari 2021

[15] Welasih, B. . \& Wirjatmadi, B. 2012. Beberapa faktor yang berhubungan dengan status gizi balita stunting. Tanaffos $11,12-17$

[16] Wellina, W. F., Kartasurya, M. I. \& Rahfilludin, M. Z.2016. Faktor risiko stunting pada anak umur 12-24 bulan. J. Gizi Indones. (ISSN 1858-4942) 5, 55-61 